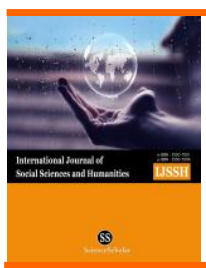

International Journal of Social Sciences and Humanities

Available online at http://sciencescholar.us/journal/index.php/ijssh

Vol. 1 No. 1, April 2017, pages: 1 8

e-ISSN : 2550-7001, p-ISSN : 2550-701X

http://dx.doi.org/10.21744/ijssh.v1i1.6

\title{
Deregulation: The Effect of Market-led Approach to Nigerian Universities Management
}

\author{
CrossMark \\ Adetunji A.T. a ; Adetunji A.V. ${ }^{\text {; }}$ Adeleke E.0. ${ }^{\text {; }}$ Madubuike S.C. ${ }^{\text {d }}$ \\ Article history: Received 1 January 2017; Accepted in revised form 20 January 2017 ; Approved 10 February 2017;
} Available online 15 February 2017

Correspondence Author

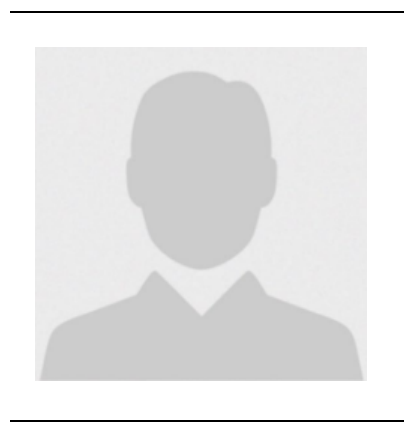

\section{Keywords}

Deregulation;

Management;

Marketing;

Nigeria;

University;
Abstract

This paper examines the effects of market-led approach Nigeria universities management concept deregulation from a market-led point of view to evaluate its effect on the management of university education in Nigeria. From many debates and argument put forward on the discussion of deregulation, it is very clear that deregulation policy was introduced for the purpose of enhancing productivities of public sectors or government owned establishment. The establishment of deregulation policy has created opportunities for different individuals and groups to participate or take ownership of some public sectors in the quest for providing better services and making profits. However widens the gap in knowledge to whether or not taking ownership of public sector business has generated profit or not. This paper is desk research and intends to review issues unturned in the past literature on how deregulation has now suddenly become a market-led approach to the Nigerian Universities Management. The paper revealed that Nigerians are keen about getting the best quality education irrespective of how the education systems are put up to be achieved. Likewise government have not been able to deregulate any of the public universities they owned rather university provisions have been commercialized and extended to private individuals.

e-ISSN: 2550-7001, p-ISSN: 2550-701X@ Copyright 2017. The Author. SS Journals Published by Universidad Técnica de Manabí. This is an open-access article under the CC BY-SA 4.0 license

(https://creativecommons.org/licenses/by-sa/4.0/) All rights reserved.

a Business Administration Department, Bowen University, Iwo, Osun State Nigeria

b Business Administration Department, Bowen University, Iwo, Osun State Nigeria

c Banking \& Finance Department, Bowen University, Iwo, Osun State Nigeria

d Sociology Department, Bowen University, Iwo, Osun State Nigeria 


\section{Contents}

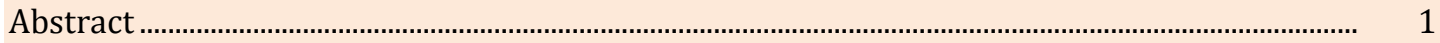

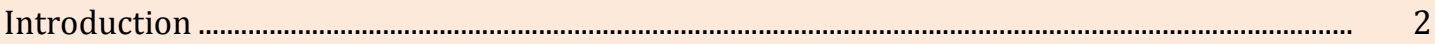

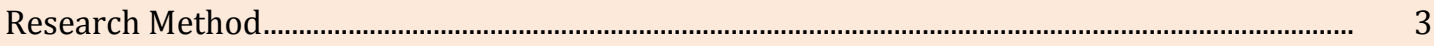

Deregulation of University Education in Nigeria ................................................................................... $\quad 3$

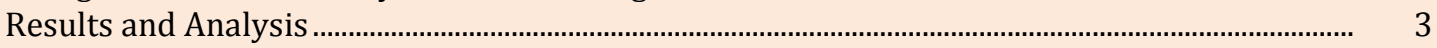

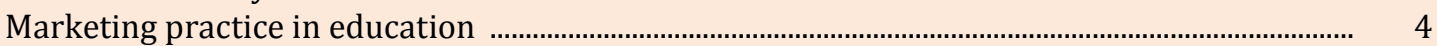

Effect of market-led approach to Nigerian Universities Management................................................ $\quad 4$

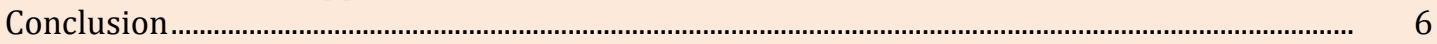

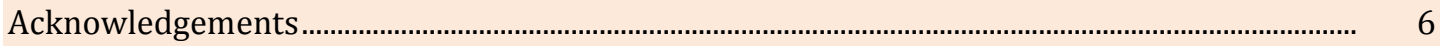

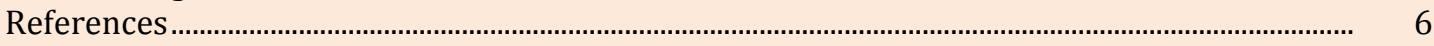

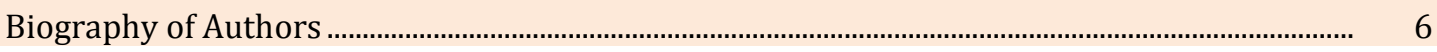

\section{Introduction}

The University prides itself as the highest citadel of learning for the production of high-level human resource for the labour market (Ekundayo and Ajayi, 2009). Obasi, Akuchie, Obasi, (2010) expressed that the Federal Government of Nigeria in recognition of the importance of educaation took appropriate steps to ensure equity with regard to access to university education. It equally anticipated the role of (higher) education in disseminating national unity. This unitization of Universities was further strengthened with the creation of the Joint Admissions and Matriculation Board (JAMB) by Act (No. 2 of 1978) of the Federal Military Government (Joint Admissions and Matriculation Board, 2004). The main aim for the establishment of the Joint Admissions and Matriculation Board (JAMB) was to provide an opportunity for eligible Nigerians to have access to university education, and to diversify the intakes, and achieve a high rate of national spread in the placement of applicants into universities in Nigeria (JAMB, 2004).

In addition, the Joint Admissions and Matriculation Board (JAMB) was to place suitably qualified candidates into the existing tertiary institutions after taking into account the vacancies available in each tertiary institution. Placement was to be done on the basis of merit, catchment area, quota system and with a special focus on females and the Educationally Less Advantaged States. Emphatically, paragraph 40 (b) of the National Policy on Education states that financial consideration alone will not be the conclusive bar to access higher education for any one who can benefit from it (Federal Government of Nigeria, 2004). To ensure this was achieved, it was also emphasized in the policy that university education will continue to be free and that a combination of scholarships and loans will continue to be used to assist indigent but brillant students to gain access to universal education.

With this good intension the operation of university education was invented, but in the recent time due to so many challenges faced by the Nigerian government prior to the period of first democracy in the country, the university management had been facing so many challenges among which scholars like Okebukola, 2002; Ojerinde, 2010; Adetunji, 2015; 2016 have written about (such as overcrowding, low funding, lack of facilities, poor learning environment among others), but yet these problems remain unsolved. The major problem of all is government inability to provide access for the Nigerian and the biggest of it is poor financing of the sector. This also led to many other problems as observed by Adetunji (2016) that financial problem is the origin of corrupt practices that now affects every business activities in the country. In other to correct all these problems the Nigerian government continue to seek for loan from the World Bank, Nigerian government was then advice to deregulate the activities of the university (Bako, 2002). But rather the government privatised the university by using it as a means to solve the problem of accessibility while the problem of finance still continue to cause problems within the public universities (Adetunji and Adetunji, 2015). 
Likewise Faniran (2012) opined that in the time past, attempts have been made to partially deregulate university education in Nigeria by involving state governments, private individuals and organizations in the establishment, funding and management of Universities in Nigeria. This has no doubt brought about unprecedented expansion of university education in Nigeria. For instance, the number of universities has risen from six in 1975 to 47 in 2000 and 125 in 2015 (NUC Bulletin, 2015). And toward the end of 2016, the number of licenced universities had grown to 40 federal, 44 states, 68 private (NUC Bulletin, 2016). Therefore the gap identify to be fill by this paper is, how deregulation meant to be a policy to improve funding system and creation of more access for the Nigerian to benefit had led to marketing language that had creates opportunities for private investors to expand their shares in the creation of new universities why the problem of funding remain unsolved. This paper intends to examine the effects of market-led approach to solving the problem of access and funding in the Nigerian universities settings. The preminary study by Adetunji (2015a) established that the gap between creating access to the university and funding the university is wide, that means even when access are created it does not mean funds are injected for right reasons. However, this observation call for proper investigation on how the university had been deregulated.

\section{Research Method \\ Deregulation of University Education in Nigeria}

The concept deregulation is seen to have different meanings and can be view in different ways. The term deregulation primarily is an economic term that developed from the free market economy of Adam Smith (Encarta Encyclopedia, 2003). Government rules and regulations governing the operation of the system are relaxed or held constant in order for the system to decide its optimum level through competition. The concept means government less-involvement in the establishment, funding, and management of educational institutions. As a deregulated sector, education will become a private enterprise undertaken by private individuals or corporate bodies that hope to maximize profit from their investments in education not total ownership of the business (Kaplan 2002; Encarta Encyclopedia, 2003). Adetunji (2015) writes in support of this assertion that deregulation of university education will mean private establishment having their shares in the running and servicing of the sector will creates a meaningful and application of the policy.

\section{Results and Analysis}

Although, Adetunji and Adetunji (2015) established that deregulation of the university has been linked with privatization where the university will have to be self-regulated and controlled; that is, freedom from government imposed decisions. Adetunji and Adetunji claimed that research showed that the initiatives for deregulation of education system have been taken by some developed and developing countries that care to improve from traditional approach to conventional way of doing things (Tsai, 2001). In the United States, the main focus of education deregulation is in the area of parental freedom to control their children's schooling. In Britain, too, deregulation has brought about autonomous schools, with greater responsibility placed on the schools to determine their own destinies. While in Nigerian education system, deregulation policies primarily emphasize privatization bordering on funding (Denise, 2002 \& Alabi, 2005). The approach was used successfully in the United State of America while parents get less involved in their children's education especially at the tertiary level. Likewise in the United Kingdom, university operates autonomously without any interference from the government or any organisation. While, in Nigeria, the proposed intension to use deregulation policy is to relieve government from funding and solve access problem which had been a long standing problems for Nigerian government since the first democratic government era.

However, the intention had been hi-jacked by Nigerian rich individual, who perceived the policy has an opportunity to enrich themselves. Likewise some political office holders who have acquired wealth through public funds also decided to establish university of their own as a

Adetunji, A., Adetunji, A., Adeleke, E., \& Madubuike, S. (2017). Deregulation: the effect of market-led approach to Nigerian universities management. International Journal of Social Sciences and Humanities, 1(1), 1-8. https://doi.org/10.29332/ijssh.v1n1.6 
capital-intensive project. These intensions that the government failed to clarify had led to the university education and education in general been capsized to another marketing language which is 'privatisation' has noted by (Adetunji and Adetunji, 2015). The reason attributable to for the mismanagement of the policy introduced what lack of procedure for policy implementation, which led to private investor thinking of what will they gain in return for their investment.

\section{Marketing practice in education}

Marketing of education is not a new concept. The state, partners for development, controlling agencies and providers (schools, colleges, universities, public and private institutions) involved themselves in the marketing of education long ago. The state and partners are committed to ensuring that the beam of education enters every house- hold and, to make education popular, different types of education marketing have already been put into place. The purpose of such marketing activities is to make the education 'product' popular. This type of education marketing can be identified as product marketing.

Product marketing of education was introduced at an early stage in the history of education, making the product of education popular within communities. After- wards, more marketing was carried out in an attempt to make different areas of learning (such as science, commerce, arts, vocational) popular. Success with such types of marketing has created a huge and diverse market. These days, a significant number of 'customers' are ready to procure different types and levels of education and this has resulted in the expansion and higher demand for university education. In an attempt to meet up with the community demand for education in general, government who took control of all education system in the country beginning to used a marketled approach to reduce their responsibilities by allowing the creation of private education institutions. Private provision is now available at every level of education (that is, elementary, secondary and tertiary). However, this study is mainly centred on tertiary (that is university), considering their establishment with little or no public funding available. Although in all fairness the introduction of market led approach has resulted in rapid expansion of private education, which has encourage the introduction of 'brand, pricing has marketing' concept.

In consideration of marketing practice in education, it may be noted that four main types of approach currently exist: 'product', 'category', 'brand' and 'pricing' marketing.

State and donor agencies are heavily involved in the marketing of education as a product. Moreover, to ensure gender and other equality (That is economic, urban and rural, ethnic minority) in education, a 'demographic segmentation concept' of marketing education is also introduced. While religious groups involve themselves in product marketing, they also work to establish 'psychographic segmentation' of marketing in education to reflect their outlook. In the 1990 's the introduction and rapid expansion of education through public universities were opened up the marketing horizon of 'geographic segmentation' in education in order to service the targeted elite groups (that is each states). However the wheel of change in establishing private universities does not considered this factor as an important one. The effect of not complying with geographical segmentation of marketing in establishing privately owned university education has caused different services to different groups and communities. This had generally brought about a number of advantages and disadvantages (that is more universities established in southwest more than any part of the country).

\section{Effect of market-led approach to Nigerian Universities Management}

To start with, it worth establishing that any marketing language is a purpose driven words, with the intention to increase sales, customers satisfaction and out rightly maximise profit or gain. While the main aim of any institution is not to make profit but rather to develop the economy. But having introduced marketing language (such as customer satisfaction, value for money, profit, break even, competitive edge) to the university education, the need to gear up competition has risen and the market has suddenly become very competitive. This was evidence in the work of Dauda (2010), he holds the view that the world is changing fast and competition is becoming stiffer, so aside from the fact that producers want to maximize profit, it may therefore 
be wise to see customers as the bridge to their success. No wonder Harvey and Williams's definition of quality simply states that quality is achieved when goods or services meet the expectation of a customer (Harvey and Williams, 2010). Customers' buying patterns or definitions of quality may differ based on exposure, resources or locality. Ishikawak (1985) claims that many companies that provide both goods and services tend to make room for customer feedback, which gives them an opportunity to improve. On this note, Townsend and Gebhardt (1990) debated the claim by Ishikawak (1985) that quality is everybody's business, including the business of the consumer.

Speaking about market-led approach to universities system, it involves a deeper reflection upon education operation itself, as it relates to Nigeria in particular. University education is seen as a starting point in the development of the nation, in that it moderates and influences national development (Ojerinde, 2010). In principle, Oko (2011) revealed that the university education management of a country influences development, the life of the country and its economic growth. As a result, in developed countries, greater attention is being paid to how university management is assembled and managed (Kaul, 2010). In light of this, it is agreed that the university education management of a country plays an important role in the overall development and outcome of the nation (Ogbogu, 2013).

From the above, it is evident that efficient management of the university education system is very important and has a vital bearing on how the quality of labour and manpower of the country are developed as well as on national economic growth (Peters, 2009). However, one can easily agree that the overall development of a nation is based on the fact that highly skilled manpower development of any country is ultimately developed and trained through competitiveness that is how best one can gets what he/she wants from the institution (Ekundayo and Ajayi, 2009). In light of these facts, university education in Nigeria is seen as a means of development, taking into consideration human input as an important aspect of management as well as the uniqueness of the nation structure in general (Akinyemi and Abiddin, 2013). Likewise, in another review by Wheelen and Hunger (2011), they hypothesized that management includes the putting into practice of business objectives (such as mission and vision statement), with the purpose of realizing business gains as a result. While the marketing-led approach of privatisation and commercialisation is having direct impact on how well an institution is run, which contradict the intension of the government to why the university education are established.

Again, let review what the term 'management' means as it relates to higher education and university is commercial in nature. That is, when the word 'management' is applied in a setting like higher education or university, there must be an expectation of 'gains and profit', as management takes place in business for the single aim of profit survival and advancement (Wheelen and Hunger, 2011). Likewise, every business operates mainly for profitability and survival: therefore, a university as a centre of the business of human development strives to be well managed for the purpose of attaining its goals of the development and creation of relevant skills for the society, as well as profitability and survival. In light of this observation, researchers such as Dauda (2010) and Smart and Paulsen (2011) have hypothesized that institutions of higher learning, including universities, are predominantly for the business of moulding people into useful skills and capacities for improvement at individual, organizational and national levels. In theory, the principle and practices of an institution of higher learning or a university are not expected to function for business gain or profit - as a matter of fact, universities are 'not for profit-making' (Oyewole, 2009, p. 324). But with the invention of the market-led approach of privatisation and commercialisation it is very difficult to hold the claim that university is not expected to make profit especially those (private universities) established in the period the policy of deregulation was introduced.

It is of a true that government who these institution claims to be supporting in developing sound citizenry tends not to inject any funding's into the management of these private universities, which has resulted in these universities putting up different prices as tuition fees

Adetunji, A., Adetunji, A., Adeleke, E., \& Madubuike, S. (2017). Deregulation: the effect of market-led approach to Nigerian universities management. International Journal of Social Sciences and Humanities, 1(1), 1-8. https://doi.org/10.29332/ijssh.v1n1.6 
for the students they admits. Even with some of this universities charging more above the government owned institution, most of these universities still struggle to pay their staff salaries while some cannot be called a place of higher learning with the kind of structure they use. Although, it may be difficult or too soon to analyse at this pointes to whether or not quality of the education provided by these private institutions are similar to that of those in the public universities where fees are charge at a very lower rate due to government involvements.

\section{Conclusion}

Nigeria is currently witnessing a period during which education and professional development at the university level are in increasing demand and the cost of providing this education has continued to rise astronomically. Hence, government cannot bear alone. In solving the cost and access issues government had introduced deregulation policies, however the policy was not well managed and instead of deregulating the sector, it has been privatised. Therefore, the process of deregulation that was supposed to be a relief to the government and the populace is now a pain bearing for them as many private universities established are charged more than ten times the tuition fees of the government owned university. Although, if you compare what they have been charged with what is obtainable in the Western context you will discover that the Nigeria universities are under-pricing. To clarify further at the time foreign exchange rate was still N420 to a dollar (\$1), Nigerian highest charged tuition fees was N630,000 that is equivalent of $\$ 1500$. At the time when the least paying tuition fees in any Western country is not less than $\$ 7500$. The margin is wide, given a justification that the adoption of privatisation policy instead of deregulation do not make any much different.

Yet if one compare Nigeria with the global trend of deregulation practices in other countries, the deregulation of university education in Nigeria seems inevitable because most state universities can not finance the accreditation of the courses to talk of effectively running the system. While the demand for quality education is the request of an average Nigerians. In addition it worth noting that of a true Nigerian government are yet to deregulate any of the public universities they owned rather they have used it as a market-led approach to encouraged other private participants to own there own university. However, while more private individuals or organizations are encouraged to establish, finance, and manage private universities, educational planners and administrators, as well as state and federal governments, should through appropriate channels, ensure that educational standards are not compromised and that citizens are not unnecessarily exploit.

\section{Acknowledgement}

My deep and sincere gratitude were presented to God for having granted me the ability and the opportunity to complete this paper. As well as, I have much appreciated to my friends for their support, suggestion, contribution in finishing this research. I would like thanking to Maria that has given me a good advisement. Last but not least, I dedicated my dreadful thank to my friend who those as editor in SS of International Journal.

\section{References}

1. Adetunji, A. T. \& Adetunji A. V. (2015). Deregulation Policy: Impact on Nigerian Universities, international journal in management \& social science, 3(8), 313-321.

2. Adetunji, A. T. (2015). Quality Issues: Beyond The Nigerian Institution. International Journal of Research Studies in Management, 4(2), 3-13.

3. Adetunji, A. T. (2015a). Implementing government policies in university education: challenges faced by Nigerian universities' principal officers. Net Journal of Social Sciences, 3(1), 9-16.

4. Adetunji, A. T. (2016). Problems hindering Quality Provision in Nigerian Universities a review of academic officers. International Journal of Management and Social Sciences Research, 5(2), 38-45 
5. Adetunji, A. T., Adetunji, A. V., Adeleke, E. O., \& Madubuike, S. C. (2017). Deregulation: The Effect of Market-led Approach to Nigerian Universities Management. International Journal of Social Sciences and Humanities (IJSSH), 1(1), 1-8.

6. Akinyemi, G. M. and Abiddin, N. Z. (2013). Quality Administration and Management in Higher Education in Nigeria: Implications for Human Resource Development. International Education Studies, 6(4), 225235 .

7. Alabi, A. T. (2006). 'Deregulation of Nigerian university education: issues \& challenges', African Journal of Educational Study, 4(1), 61-74.

8. Amerta, I. M. S. (2017). The Role of Tourism Stakeholders at Jasri Tourism Village Development, Karangasem Regency. International Journal of Social Sciences and Humanities (IJSSH), 1(2), 20-28.

9. Astawa, I. N., Mantra, I. B. N., \& Widiastuti, I. A. M. S. (2017). Developing Communicative English Language Tests for Tourism Vocational High School Students. International Journal of Social Sciences and Humanities (IJSSH), 1(2), 58-64.

10. Bako, S. (2002). Union, state and the crisis of higher education: the latest phase of struggle for and against restructuring and deregulating the Nigerian universities - a paper presented at the 1CORDESRIA General Assembly held in Kampala, Uganda, December 8 - 12.

11. Basak, A., \& Khanna, K. (2017). A Study on the Selection Criteria of Different Hotels of Delhi NCR in Accordance to the HR Policies and Market Trends. International Journal of Social Sciences and Humanities (IJSSH), 1(1), 27-38.

12. Billaiya, R., Malaiya, S., \& Parihar, K. S. (2017). Impact of Socio Economic Trends on Students in Quality Education System. International Journal of Social Sciences and Humanities (IJSSH), 1(1), 16-20.

13. Cedeño, M. L. D., Arteaga, M. G. D., Pérez, A. V., \& Arteaga, M. L. D. (2017). Regulatory Framework for Renewable Energy Sources in Ecuador Case Study Province of Manabí. International Journal of Social Sciences and Humanities (IJSSH), 1(2), 29-42.

14. Dauda, R. O. S. (2010). Investment in Education and Economic Growth in Nigeria: An Empirical Evidence. International Research Journal of Finance and Economics (55), 158-169.

15. Denise, M. (2002). Deregulating education in the United States, from vouchers to home schooling to the end of voluntary desegregation. Retrieved on November 15, 2009 from: http://www.writ.news.findlaw.com/commentaries

16. Ekundayo, H. T. \& Ajayi, I. A. (2009). Towards effective management of university education in Nigeria. International NGO journal, 4(8), 342-347.

17. Ekundayo, H. T. and Ajayi, I. A. (2009). Towards effective management of university education in Nigeria. International NGO journal 4(8), 342-347.

18. Encarta Encyclopedia (2003). 'Deregulation of education in Nigeria: implications for access to university education', cited in D. Omoike \& O. U. Gbinigie (2004), paper presented at the National Conference on Deregulation in a Globalized Economy, held at the Faculty of Social Sciences, Ambrose Alli University, Ekpoma, Nigeria.

19. Faniran, J. O. (2012). Deregulation as a means of enhancing university educational financing in Nigeria, British Journal of Arts and Social Sciences, 8(I), 17-23.

20. Federal Government of Nigeria (2004). National Policy on Education. (Revised). Lagos: NERDC Press.

21. Gámez, M. R., Pérez, A. V., Será, A. S., \& Ronquillo, Z. M. (2017). Renewable Energy Sources and Local Development. International Journal of Social Sciences and Humanities (IJSSH), 1(2), 10-19.

22. Ghosh, C. (2017). A Study on-Evaluating Marketing Strategies Adopted by Home Appliance for Economic Development in India. International Journal of Social Sciences and Humanities (IJSSH), 1(1), 9-15.

23. Harvey, L. and Williams, J. (2010). 'Fifteen years of quality in higher education'. Quality in Higher Education 16(1), 3-36.

24. Ishikawa. (1985). What is quality control? The Japanese way, translated by David J. Lu, Prentice-Hall /Englewood Cliffs, New Jersey, USA.

25. Kaplan, D. (2002). Education Is Not a Commodity. Paper presented at the International Conference against Deregulation held in Berlin, February.

Adetunji, A., Adetunji, A., Adeleke, E., \& Madubuike, S. (2017). Deregulation: the effect of market-led approach to Nigerian universities management. International Journal of Social Sciences and Humanities, 1(1), 1-8. https://doi.org/10.29332/ijssh.v1n1.6 
26. Kaul, J. N. (2010). Higher education, social change and national development. [Online]. Available at http://14.139.58.196:8080/xmlui/handle/123456789/169 [Accessed 11 September 2016].

27. Maba, W. (2017). Teacher's Perception on the Implementation of the Assessment Process in 2013 Curriculum. International Journal of Social Sciences and Humanities (IJSSH), 1(2), 1-9.

28. Maba, W., \& Mantra, I. B. N. (2017). An Analysis of Assessment Models Employed by The Indonesian Elementary School Teachers. International Journal of Social Sciences and Humanities (IJSSH), 1(1), 3945.

29. National Universities Commission, 2014. Monday bulletin. Publication of office of the executive secretary 9,

[Online].

Available

at

http://www.nuc.edu.ng/nucsite/File/Monday\%20Bulletin/MB\%202014/MONDAY\%20Bulletin\%2020 -01-2014.pdf [24 July 2016].

30. Obasi, I. N., Akuchie, R. C. \& Obasi, S. N. (2010). Expansion of Higher Education Access through Private Universities in Nigeria (1999-2009): A Decade of Public Policy Failure? Paper presented at a National Conference on Education for Nation Building and Global Competitiveness, organized by NERDC at the International Conference Centre, Abuja.

31. Ogbogu, C. O. (2013). Policy Issues in the Administration of Higher Education in Nigeria. World Journal of Education 3(1), 32-38.

32. Ojerinde, D. (2010). Unified Tertiary Matriculation Examination (UTME): Prospect and Challenges: $A$ Keynote Address at the National Education Conference on 30th -31st March, 2010, Nigeria.

33. Okebukola, P. (2002). The State of University Education in Nigeria. Abuja: National Universities Commission.

34. Oko, R. O. (2011). Toward transforming Nigerian universities for quality education: The need for Nigerian universities professors' forum (Nov, 14). [Online]. Available at http://newsdiaryonline.com/ professor.htm \#sthash.07DodxH4.dpuf [Accessed 12 November 2015].

35. Omoike, D. \& Gbinigie, O. U. (2005). 'Deregulation of education in Nigeria: implications for access to university education', in A. S. Akpotor, M. E. Omohan, B. O. Iganiga, O. M. Aigbokhavbolo \& A. O. Afolabi (eds) Deregulation \& Globalisation in Nigeria: Issues \& Perspectives. Ekpoma: AAU Publishing House, 127-237.

36. Oyewole, 0. (2009). Internationalization and its implications for the quality of higher education in Africa. Higher Education Policy, 22(3), 319-329.

37. Peters, A. A. (2009). Population and Human Resource Development in Nigeria. lecture delivered at the National Defence College. Abuja Nigeria to Participants of Course, 18(7). [Online]. Available at http://www.ndc.gov.ng/Lectures/Population-and-HRD.pdf [Accessed 12 September 2013].

38. Smart, J. C. and Paulsen, M. B. (2011). Higher education: Handbook of theory and research (26). Springer. [Online]. Available

at http://books.google.com.my/books?hl=en\&lr=\&id=30Z6ymPgjGgC\&oi=fnd\&pg=PR5\&dq=University+a s+education++business+center\&ots=m0fZp8XsMH\&sig=GEZ88AoGBL6QowL68Hm_rSS3dy8 [Accessed 10 May 2016].

39. Suparsa, I. N., Mantra, I. B. N., \& Widiastuti, I. A. M. S. (2017). Developing Learning Methods of Indonesian as a Foreign Language. International Journal of Social Sciences and Humanities (IJSSH), 1(2), 51-57.

40. Suryasa, I. W., Prayoga, I. G. P. A., \& Werdistira, I. W. A. (2017). An Analysis of Students' Motivation Toward English Learning As Second Language Among Students In Pritchard English Academy (PEACE). International Journal of Social Sciences and Humanities (IJSSH), 1(2), 43-50.

41. Townsend, P. L. and Gebhardt, J. E. 1990. Commit to quality. New York;Chichester: Wiley.

42. Tsai, C. (2001). 'The deregulation of higher education in Taiwan'. Retrieved from: http://www.bcedu/bc_org/avp/soe/cihe/newsletters (15 November 2009).

43. Wheelen, T. L. and Hunger, J. D. (2011). Concepts in strategic management and business policy. Pearson Education India. 